\title{
Development and Decline of the Interest in Dermatoglyphics
}

\author{
Giovanni Floris* \\ University of Cagliari, Italy \\ *Corresponding Author: Giovanni Floris, University of Cagliari, Italy

\begin{abstract}
The development of the interest in the dermatoglyphic studies from the first works on fingerprints to an increasing number of works was illustrated. The next decline since 2010s was also illustrated. A wideranging bibliography concerning authors and journals dealing with dermatoglyphics confirms what has been reported.
\end{abstract}

Key words: dermatoglyphics

\section{DISCUSSION}

Leaving aside the pioneering works on fingerprints by Galton, 1892; Henry, 1901; Wilder, 1904; Bonnevie, 1924 (to name just a few), it was in the article by Cummins and Midlo (1926) that the term "dermatoglyphics" was introduced to indicate the set of ridges and furrows present on the fingerprints, the palm of the hand and the sole of the foot. However, it was with the fundamental work of Cummins and Midlo (1943), with a new edition in 1961 that the study of dermatoglyphics took hold not only in criminal anthropology but also in medicine, biology, population biology, embryology, primatology, paleodermatoglyphics and pathology. The increase in studies concerning dermatoglyphics was due above all to: the methodological simplicity of their recording, usually by means of the non-invasive and inexpensive ink method; their immutability starting from 4-5 months of intrauterine life when they are fully formed; their genetic basis (not fully clarified but mainly polygenic which makes them less sensitive to random variations); etc. More or less from the $1960 \mathrm{~s}$ onwards, there was an increasing number of both conference (or sections of conferences) dedicated to dermatoglyphics and books reporting the related studies or new studies. There were several generalist books from 1969 (edited by W. Hirsch) to 2000 (edited by NM Durham, KM Fox, CC Plato) (see literature cited), accompanied by other more specialistic ones such as those by: Holt, 1951-1968; Alciati, 1960 a; Penrose, 1963-1965; Weninger, 1965-1973; Dallapiccola, 1968; Loeffler, 1969; Plato, 1970; Schaumann and Alter, 1976; Babler, 1978; De Wilde et al., 1981; De Wilde, 1979; Malhotra and Reddy, 1984; Giuliani, 2004; until to Tornjova-Randelova and Paskova-Topalova, 2011. Works on individual populations increased, and here I will cite, for purposes of brevity, only 1 or 2 publications per author and, for the same reason, generally only those authors who made the study of dermatoglyphics their main field of research: Pons, 1952-1954; Alciati, 1960 b; Mavalwala, 1962; Atasu and Telatar, 1968; Sunderland, 1968; Singh, 1971; Bhanu, 1972; De Stefano, 1974; Gyenis, 1974; Floris, 1975-1977; Plato et al., 1975; Rudan, 1975; Aue-Hauser, 1976; Oyhenart-Perera, 1979; Aue-Hauser et al., 1980; Matznetter, 1983; Hauser and Abraham, 1985; De Diaz Ungria, 1986; Sorensen Goodson, 1986; Gualdi Russo, 1987; Pospisil, 1987; Heet, 1990; Milicic and Rudan, 1991; Reddy, 1992; Atasu, 1993; Sokal, 1993; Sanna and Floris, 1995; Kralik et al., 2002; Nagy, 2005; Karmakar et al., 2007; Cam et al. 2008). And there were many others. Naturally, scientific journals published many studies and in fact the American Journal of Physical Anthropology dedicated number 2 of volume 42, 1975, entirely to works on dermatoglyphics, as did the International Journal of Anthropology with number 1 of volume 13, 1988 and number 1-2 of volume 20,2005. In 1965 the first number of Dermatoglyphic-News Bulletin (SB Holt, ed.) was published. The journal continued for years and then gradually declined in a climate of general indifference, It can be said that the interest in dermatoglyphics also decresed more or less starting from 2005, probably with the increase in our knowledge of DNA and related characters. As proof of this, in 2018 (investigation by A.) no 
study concerning dermatoglyphics appeared in the following journals: American Journal of Physical Anthropology; Human Biology; American Journal of Human Biology; Anthropologischer Anzeiger (data available for 2013; The Anthropologist (data available for 2017); Human Heredity (2017/2018); Annals of Human Biology; Journal of Anthropological Sciences; Annual Review of Anthropology; Current Anthropology (which at least published one, but back in 1981; Floris, 1981), with one exception: Homo-Journal of Comparative Human Biology (in which there appeared one study out of a total of 40). Rather little, I would say.

Therefore, have studies on dermatoglyphics disappeared? No, not at all, because many publications have appeared more or less since the 2010s, generally dealing with various pathologies (ranging from diabetes to psoriasis, schizophrenia, obesity, blindness, etc.) in the most disparate journals, such as: International Journal of Pharma. Research and Health Sciences; International Research Journal of Management Sociology \& Humanities; Journal of Health and Allied Sciences; International Journal of Medical Science Research and Practice, and so on). Fingerprints were investigated for the most part, and obviously not always with citations of those who have a long published on these same topics; but evidently time erase everything. Among the above-mentioned journals, only Homo and Human Biology Review continued to occasionally publish works on dermatoglyphics.

\section{CONCLUSION}

In conclusion, it can be hoped that the study of dermatoglyphics will recover the vigour it has shown in past years, for example by relaunching the Bulletin and realizing that the results achieved are not different from those obtained with more modern and sophisticated methodologies.

\section{LiTERATURE CITED}

[1] Alciati G. 1960 a. Sulla metodologia per lo studio dei rilievi cutanei palmari. Rivista di Antropologia 47:89-127.

[2] Alciati G. 1960 b. Sui rilievi cutanei palmari dei Zapotechi (Oaxaca, Messico). Scienza e Tecnica 4 (3): 127-131.

[3] American Journal of Physical Anthropology. 1975. 52 (2).

[4] Atasu M, Digital and Palmar Dermatoglyphics of Turkish Children. 1993. Newsletter of the ADA. 12 (1): 3-8.

[5] Atasu M, Telatar H. 1968. Cancer and Dermatoglyphics. Lancet 1: 861.

[6] Aue-Hauser G. 1976. Fingerbeerenmuster und quantitative werte von 1000 males and 1000 females Wienerce. Mitteilungen des Anthropologischen Gesellschaft in Wien, 106: 126-141.

[7] Aue-Hauser G, Okajima M, Wytek R. 1980. Digital Flexion Creases in Japanese. The Journal of the Anthropological Society of Nippon 88 (4):443-454.

[8] Babler WJ. 1978. Prenatal Selection and Dermatoglyphic patterns. American Journal of Physical Anthropology 48: 21-28.

[9] Bhanu BV, Malhotra KC. 1972. L'angle atd chez les Ezhravas de Kerala, L'Anthropologie 76 (7-8): 741746.

[10] Bonnevie K. 1924. Studies in papillary pattern of human fingers. Journal of Genetics 15: 1-111.

[11] Cam FS, Gul D, Tunca Y, Fistik T, Erdogan MO, Yildiz H, Erdem S, Solak M. 2008. Analysis of the dermatoglyphics in Turkish patients with Klinefelter's syndrome. Heriditas 145: 163-166.

[12] Cummins H, Midlo C. 1926. Palmar and Plantar Epidermal Ridge Configurations (Dermatoglyphics) in European-Americans. American Journal of Physical Anthropology 9 (4): 471-502.

[13] Cummins H, Midlo C. 1943 (1961). Finger Prints, Palms and Soles. An Introduction to dermatoglyphics. Dover Publications. Inc. New York.

[14] Dallapiccola B. 1968: I dermatoglifi della mano. Zambon S.p.A. Milano-Vicenza.

[15] De Diaz Ungria AG. 1986. Qualitative Finger Dermatoglyphics of Venezuelan Yupka Natives. International Journal of Anthropology 1 (1): 9-18.

[16] Dermatoglyphics-News Bulletin. 1965. No. 1 (SB Holt ed.).

[17] Dermatoglyhics. An International Bibliography. 1977. (J Mavalwala ed.). Mouton Publishers. The HagueParis.

[18] Dermatoglyphics. An International Perspective. 1978. (J Mavalwala ed.). Mouton Publishers. The HagueParis.

[19] Dermatoglyphics: Science in Transition. 1991. (CC Plato, RM Garruto, BA Schaumann ed.). Wiley-Liss. 
[20] Dermatoglyphics Today. 1991. (BM Reddy, SB Roy, BN Sarkar, ed.). Indian Statistical Institute. Calcutta.

[21] De Stefano GF, Jenkins JJ. 1974. Studio preliminare sui dermatoglifi di popolazioni Nicaraguensi, Journal of Human Evolution 1: 1-16.

[22] De Wilde AG. 1979. Developmental Aspects of Ridges and Creases (Dermatoglyphics). Collegium Antropologicum 3 (2): 201-210.

[23] De Wilde AG, van Meulenaarsgraf H, Pleeging JH, Amez-Voorhoeve WHM. 1981. a Proposed Classification for Fingerpatterns. Dermatoglyphics 9 (2): 64-80.

[24] Floris G. 1975. Sex and Side Differences and Correlations Between Quantitative Palmar Characteristics in a Sample of Sardinian Population. American Journal of Physical Anthropology 42: 277-280.

[25] Floris G. 1977. Presence of Correlations Between the Five Palmar Area Patterns. American Journal of Physical Anthropology 47 (3): 415-418.

[26] Floris G. 1981. A Hypothesis on the Inheritance of Two Dermatoglyphic Patterns. Current Anthropology 22 (6): 700.

[27] Giuliano A. 2004. Dieci e tutte diverse. Studio sui dermatiglifi umani. Tirrenia Stampatori, Torino.

[28] Gualdi Russo E. 1987. Palmar Dermatoglyphics in a Sample of Italian Population. International Journal of Anthropology 2 (2): 105-116.

[29] Gyenis Gy. 1974. Hautleisten system untersuchungen bei Drei Ungarischen Populationen. Humanbiologia Budapestinensis. I. Budapest.

[30] Hauser G, Abraham R. 1985. Size and Shape in Dermatoglyphic Analysis of Palmar Interdigital Areas. Human Biology 12 (1): 53-66.

[31] Hautleisten und Krankheiten. 1969. (W Hirsch, ed.). Grosse Verlag. Berlin.

[32] Heet HL. 1990. Dermatoglyphics of the Finno-Ugrians of Eurasia, in: Trends in Dermatoglyphic Research (NM Durham, CC Plato, ed.): 218-233. Kluwer Academic Publishers.

[33] Henry ER. 1901. Classification and Uses of Finger-Prints. George Routledge and Sons, Ltd. London.

[34] Holt SB. 1951. The Correlations Between Ridge Counts on Different Fingers. Annals of Eugenics 16 (3): 287-297.

[35] Holt SB. 1968. The Genetics of Dermal Ridges. Cc Thomas Publisher. Springfield, Illinois, USA.

[36] Karmakar B, Yakovenko K, Kobyliansky E. 2007. Qualitative Finger and Palmar Dermatoglyphics: Sexual Dimorphism in the Chuvashian Population of Russia. Anthropologischer Anzeiger 65 (4): 383-390.

[37] International Journal of Anthropology. 1988: 13 (1).

[38] International Journal of Anthropology. 2005: 20 (1.2).

[39] Loeffler L. 1969. Papillarleisten-und Hautfurchensystem. Human Genetik 1/2. George Thieme Verlag. Stuttgart.

[40] Loesch D. 1974. Genetical Studies of sole and palmar dermatoglyphics. Annals of Human Genetics 37: 405-420.

[41] Malhotra KC, Reddy BM. 1984. Genetics of Finger Ridge Counts. Indian Statistical Institute. Calcutta.

[42] Matznetter T. 1983. A dermatoglyphic study about a mixed population from Northern Brasil (Belèm, Parà). Garcia de Orta, Sèr. Anthropologia 2 (1-2): 207-220.

[43] Mavalwala JD. 1962. Correlations Between Ridge Counts on All Digits of the Parsus of India. Annals Human Genetics 26: 137-138.

[44] Methoden der Dermatoglyphik. Anthropologie. 1988. Sonderdruck. Gustav Fischer Verlag-Stuttgart-New York.

[45] Nagy AS, Pap M. 2005. Pattern Influence on the Fingers. Homo 56 (1): 51-67.

[46] Oyhenart-Perera MF. 1979. Contribucion al estudio de los dermatoglifos digitales de la poblacione de Montevideo (Uruguay), II, Caracteres cuantitativos. Revista de Biologia del Uruguay 7 (2): 65-76.

[47] Penrose LS. 1963. Finger-Prints, Palms and Chromosomes. Nature 9: 933-938.

[48] Penrose LS. 1965. Dermatoglyphic Typology. Nature 205: 544-546.

[49] Plato CC. 1970. Polymorphism of the C Line of Palmar Dermatoglyphics with a New Classification of the C Line Terminations. American Journal of Physical Anthropology 33: 413-420.

[50] Plato CC, Cereghino J, Steinberg FS. 1975. The Dermatoglyphics of the American Caucasians. American Journal of Physical Anthropology 42: 195-210.

[51] Pons J. 1952. Impresiones dermopapilares en estudiantes universitarios barceloneses. Trabajos del Instituto Bernardino de Sahagun de Antropologia y Etnologia 13 (2): 87-131. 
[52] Pons J. 1954. Impresiones dermopapilares en vascos y su relation con otras poblaciones. Trabajos del Insituto Bernardino de Sahagun de Antropologia y Etnologia 14 (3): 58-78.

[53] Pospisil MF. 1987. Correlation analysis of the finger ridge count in Cuban population. Acta Facultatis Rerum Naturalium Universitatis Comenianae. Anthropologia 32-33: 65-79.

[54] Progress in Dermatoglyphic Research (CS Bartsocas ed.). 1982. Alan R. Liss Inc. New York.

[55] Reddy BM, Reddy PC. 1992. Dermatoglyphic Affinities among the Telugu Populations with Contrasting Ethnohistorical Blackgrounds. American Journal of Human Biology 4: 669-682.

[56] Schaumann B, Alter M. 1976. Dermatoglyphics in Medical Disorders. Springer-Verlag. New York.

[57] Sanna E, Floris G. 1995. Polymorphism of Palmar Main Line Terminations as an Indicator of Relationships Among Sardinian Linguistic Groups of Males. Human Biology 67 (2): 265-282.

[58] Singh S. 1971. quantitative and Qualitative Analysis of the Dermatoglyphics of the Palms of Australians of European Ancestry. Human Biology 43: 486-492.

[59] Sokal R, Livshits G. 1993. Geographic Variation of Six Dermatoglyphic Traits in Eurasia. American Journal of Physical Anthropology 90: 393-407.

[60] The State of Dermatoglyphics. The Science of Finger and Palm Prints (NM Durham, KM Fox; CC Plato ed.). 2000. The Edwin Mellen Press. UK.

[61] Trends in Dermatoglyphic Research (NM Durham, CC Plato ed.). 1990. Kluwer Academic Publishers.

[62] Sorenson GC, Meier RJ. 1986. Easter Islander Palmar Dermatoglyphics: Sexual Dimorphism, Bilateral Asymmetry and Family Polymorphism. American Journal of Physical Anthropology 70 (1): 125-132.

[63] Sunderland E, Ryman R. 1968. P.T.C. Thresholds, Blood Factors, Colour Vision and Fingerprints of Jivaro Indians in Eastern Ecuador. American Journal of Physical Anthropology 28 (3): 339-344.

[64] Tornjova-Randelova S, Pakova-Topalova D, Yordanov Y. 2011. Dermatoglyphics in Anthropology and Medicine. Sofia.

[65] Vrydagh-Laoureux S. 1979. Digital and palmar dermatoglyphics in a sample of Moroccans. Human Biology 51 (4): 537-549.

[66] Weninger M. 1965. Dermatoglyphic Research. Human Biology 37: 44-56.

[67] Weninger M. 1973. Some Methodological Remarks as to the Study of Finger and Palmar Dermatoglyphics, in: Physical Anthropology and its Extening Horizons (A Basu, AK Ghosh, SK Biswass, R Ghosh ed.): 109-113, Calcutta.

\section{AUTHOR'S BIOGRAPHIES}

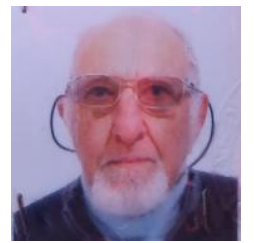

Giovanni Floris, was professor of Anthropology to the University of Cagliari (Italy) in the Department of Natural Sciences. He is author of more of 100 works about dermatoglyphics in normal and pathological subjects, blood groups, auxometry, PTC, color blindness, epigenetic cranial traits, craniometry, secular trend in stature and in menarcheal age, and other physical anthropological characteristics.

Citation: Giovanni Floris. "Development and Decline of the Interest in Dermatoglyphics" International Journal of Humanities Social Sciences and Education (IJHSSE), vol 7, no. 7, 2020, pp. 157-160. doi: http://dx.doi.org/10.20431/2349-0381.0707018.

Copyright: () 2020 Authors. This is an open-access article distributed under the terms of the Creative Commons Attribution License, which permits unrestricted use, distribution, and reproduction in any medium, provided the original author and source are credited. 